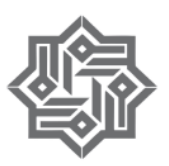

KALAM, p-ISSN: 0853-9510 e-ISSN: 2540-7759

http://ejournal.radenintan.ac.id/index.php/KALAM

Volume 10, No. 2, Desember 2016, halaman 445 - 468

\title{
Inklusivitas Pemikiran Keagamaan Abdurrahman Wahid
}

\author{
Rosidi \\ IAIN Raden Intan, Lampung \\ rosidi@radenintan.ac.id
}

\begin{abstract}
Abstrak
Makalah ini akan membahas pemikiran-pemikiran inklusiv Abdurrabman Wabid (Gus Dur). Diantaranya tentang kebidupan keberagamaan Gus Dur, Pribumisasi ajaran Islam dan Islam sebagai etika sosial. Sumber data penulisan ini dari tulisan-tulisan Abdurrabman $W$ abid sendiri seperti dalam bukunya yang berjudul : Islamku Islam Anda Islam Kita Agama Masyarakat Negara Demokrasi (2006), Islam Kosmopolitan, dan sumber lain yang terkait dengan pokok bahasan. Penelitian ini menggunakan pendekatan hermeneutic dan analisis data historis kritis. Hasil penelitian ini menunjukkan bahwa kehidupan keberagamaan yang dicita-citakan Gus Dur adalah beragama yang damai, ramah. Masingmasing umat beragama meyakini kebenaran agama yang mereka anut. Sebab hanya dengan keberagamaan yang tulus terletak makna keberagamaan yang hakiki. Gus Dur juga menginginkan agar dalam memahami Islam dikaitkan dengan masalab-masalab di negeri ini. Atau dengan kata lain Islam perlu dipribumisasikan. Meskipun Islam berasal dari Arab yang tentu saja tidak bisa dipisabkan dengan tradisinya, tetapi ketika masuk ke Indonesia dan berdialog dengan budaya Nusantara, maka harus mengubah budaya yang ada. Intinya, bagaimana memasukkan budaya lokal ke dalam Islam.
\end{abstract}

\footnotetext{
Abstract

This paper will discuss the inklusiv idea of Abdurrabman Wabid (Gus Dur). Among them the about religious life, indigenization of Islam and Islam as social ethics. It sources from the writings of Abdurrahman $W$ abid as in bis book entitled:
} 
Islamku Islam Anda Islam Kita, Agama Masyarakat Negara Demokrasi (2006), Islam Kosmopolitan, and other sources related to the subject. This study uses a hermeneutic approach and critical analysis of historical data. The results of this study indicate that religious life is aspired Gus Dur is a religion of peace, friendly. Each religious community convinced of the truth of their religion. Because only with a sincere religious diversity lies the essential meaning. Gus Dur also wants to understand Islam is associated with problems in this country. Or in other words Islam need dipribumisasikan. Although Islam is derived from the Arabic which of course can not be separated by tradition, but when it gets into Indonesia and dialogue with the cultural heritage, it must change the existing culture. In essence, how to incorporate local culture into Islam.

Keywords : Islam, Inklusivitas, Pribumisasi, Etika Sosial.

\section{A. Pendahuluan}

Gus Dur, atau nama kecilnya Abdurrahman ad-Dakhil, lahir di Jombang pada 4 Sya'ban atau 7 September 1940 di Denanyar dekat kota Jombang, Jawa Timur, di rumah pesantren milik kakeknya dari pihak ibunya, K.H. Bisri Syansuri. ${ }^{1}$ Dari garis ayah, ia adalah cucu Hadratusy Syekh K.H. Hasyim Asy'ari, sedangkan dari garis ibu, ia adalah cucu K.H. Bisri Syansuri. Dengan demikian, nasabnya baik dari garis bapak maupun ibu adalah keturunan para ulama besar dan sekaligus pendiri Nahdlatul Ulama (NU). ${ }^{2}$

Sejak kecil Gus Dur dididik dan dibesarkan dalam tradisi pesantren yang kental di bawah naungan keluarga ulama. Menurut pengakuan ibunya, sejak usia 5 tahun ia sudah lancar membaca. ${ }^{3}$ Pada tahun 1955, ia melanjutkan sekolah ke SMEP (Sekolah Menengah Ekonomi Pertama) di Gowangan, Yogyakarta. Untuk menambah pengetahuan agama, ia belajar 3 kali dalam seminggu di Pesantren Krapyak yang letaknya sedikit di luar kota Yogyakarta. Di sini ia belajar bahasa Arab kepada K.H. Ali Ma'sum, seorang kiai yang dikenal egaliter. Di pesantren ini kegemaran Gus Dur terhadap buku semakin meningkat. Karena kemampuan pemahaman bahasa Inggris yang dimiliki cukup baik, maka ketika

${ }^{1}$ Greg Barton, Biografi Gus Dur (Yogyakarta: LKiS, 2010), h. 19.

'Mujamil Qomar, NU "Liberal": dari Tradisionalisme Ablussunah ke Universalisme Islam (Bandung: Mizan, 2002), h. 164.

3Ibid., h. 165. 
usia 15 tahun ia sudah banyak bersentuhan dengan pemikiran sosialisme Karl Marx, filsafat Plato, Talles, novel-novel William Bochner, dan buku-buku lain yang dipinjam dari perpustakaan dan guru-guru yang ada di SMEP Yogyakarta. Sebenarnya di SMEP pada tahun pertama ia bukan termasuk siswa yang cemerlang, bahkan ia terpaksa mengulang kelas karena gagal dalam ujian. Kegagalan ini bukan karena kebodohan, tetapi karena seringnya ia menonton pertandingan sepak bola, sehingga ia tidak punya banyak waktu untuk mengerjakan tugas sekolah. ${ }^{4}$ Karena pelajaran yang diterima di kelas dianggap kurang menantang, maka ia merasa bosan dan lebih banyak membaca buku-buku di luar pelajaran. Ia juga masih dalam suasana duka karena kehilangan ayah tercinta. Setelah tamat dari SMEP pada pertengahan tahun 1957 ia melanjutkan belajar di Pesantren Tegalrejo Magelang di bawah asuhan K.H. Khudhori yang merupakan tokoh NU di daerahnya. Di Tegalrejo ini pula Gus Dur banyak menghabiskan waktunya untuk membaca buku-buku Barat.

Pada tahun 1959, Gus Dur pulang ke kampung halaman, Jombang, untuk belajar secara lebih serius di Pesantren Tambak Beras di bawah bimbingan K.H. Wahab Hasbullah. Selama belajar di pesantren ini, ia dipercaya untuk ikut mengajar dan menjadi kepala sekolahnya. Selama nyantri di Tambak Beras ia juga masih rajin bersilaturahmi ke Krapyak, ke kediaman K.H. Ali Ma'sum. Pada masa inilah, antara akhir tahun 1950-an hingga 1963, Gus Dur mendalami studi tentang Islam dan sastra klasik. Ia dikenal sebagai santri cemerlang. Studi ini tergantung dengan daya ingatan yang memang telah dimiliki oleh Gus Dur, walaupun ia juga dikenal sebagai sosok yang malas dan kurang disiplin dalam studi formalnya.

Pada tahun 1960, Gus Dur mendapat kesempatan belajar ke Universitas al-Azhar Mesir melalui beasiswa dari Departemen Agama. Ketika itu usia Gus Dur 23 tahun. Pada tahun 1960-an Mesir adalah kota tempat menuntut ilmu bagi para pelajar Muslim Indonesia. Universitas al-Azhar adalah universitas tertua di dunia yang sudah berusia ribuan tahun. Universitas ini berabad-abad lebih

${ }^{4}$ Greg Barton, Biografi Gus Dur, h. 49. 
tua daripada Oxford, Cambridge, Sorbonne, dan universitasuniversitas tua lainnya di Eropa. Al-Azhar adalah juga pusat dari sejumlah ide yang sangat modern dari dunia Islam. Di bawah pimpinan Muhammad Abduh, salah seorang perintis modernisasi Islam, ide-ide pembaruannya diperkenalkan di Indonesia oleh mereka yang belajar di Universitas al-Azhar.

Setelah berdiam selama satu tahun di Mesir, Gus Dur mendapat pekerjaan tetap di Kedutaan Besar Republik Indonesia. Sebagai pemimpin mahasiswa yang cemerlang dan kemampuan bahasa yang baik, maka ia dibutuhkan kedutaan besar. Ia pun bekerja setiap hari, dan dari pekerjaannya ia bisa menambah pendapatan dari beasiswa yang diterimanya untuk membeli buku, menonton film, dan keperluan lainnya. Melalui pekerjaannya ini Gus Dur mendapat kesempatan untuk bergaul dengan banyak kalangan serta banyak mendapat berita-berita terbaru dari Indonesia.

Namun, setelah 7 tahun di Mesir ia merasa tidak betah, karena menurutnya ilmu yang dipelajari sama dengan apa yang didapat di pesantren di Indonesia. Akhirnya ia pindah ke Bagdad, kota seribu satu malam, untuk melanjutkan studi pada Fakultas Sastra. Di Universitas Bagdad inilah ia bisa mengembangkan pemikiran intelektualnya. Ia bisa membaca banyak karya peneliti besar seperti Emile Durkheim dan para peneliti Barat lainnya. Di universitas ini pula ia diminta untuk menulis asal usul Islam di Indonesia. ${ }^{5}$

Selama dua tahun di Bagdad, Gus Dur memfokuskan diri pada riset mengenai sejarah Indonesia. Dosen-dosennya memberikan izin untuk menulis mengenai Islam di Indonesia. Ia kemudian banyak membaca literatur tentang Islam dan Indonesia yang ternyata banyak ditemukan di perpustakaan di Bagdad, baik yang ditulis para Orientalis maupun oleh orang Indonesia sendiri. Dengan memanfaatkan sumber-sumber yang ada, Gus Dur berhasil menyelesaikan penelitiannya dengan baik.

5Mujamil Qomar, NU 'Liberal', h. 166. 
Selama di Bagdad Gus Dur banyak tertarik pada pemikiranpemikiran kritis, baik dari ilmuwan Muslim maupun non-Muslim. Ia sangat mengagumi Paul Tillich, seorang teolog Kristen yang masyhur, renungan filsafat Muhammad Abduh, dan pemikiran Hassan Hanafi, pemikir Islam yang dianggap kekiri-kirian. Di antara pemikir tersebut, yang paling dihormati adalah Mohamed Arkoun, yang mencoba melihat Islam secara utuh. Di samping itu, dalam bidang tasawuf, Gus Dur juga sangat mengagumi al-Gazali, melalui karya monumentalnya Ibya' 'Ulum ad-Din.

Setamat studi di Bagdad, ia pun pindah ke Eropa. Mulamula ia tinggal di Belanda untuk mendapatkan kesempatan belajar di pascasarjana di bidang perbandingan agama. Akan tetapi, setelah keliling di Universitas Leiden dan universitas lainnya, ternyata hasil belajar di Bagdad tidak mendapat pengakuan di Eropa, dan mensyaratkan ia harus mengambil strata sarjana lagi. Karena kecewa, akhirnya pada pertengahan 1971 Gus Dur kembali ke tanah air.

Sepulang dari Eropa pada pertengahan tahun 1971, Gus Dur kembali ke pesantren. Ia kemudian diminta oleh yayasan keluarga untuk menjadi Dekan pada Fakultas Ushuluddin Universitas Hasyim Asy'ari Jombang hingga tahun 1974. Tahun 1976 ia banyak diminta untuk menjadi tenaga konsultan di beberapa departemen dan instansi, antara lain Departemen Koperasi, Departemen Agama, Lembaga Penelitian, Pendidikan, dan Penerangan Ekonomi dan Sosial (LP3ES), dan beberapa lembaga swadaya masyarakat (LSM), baik di dalam maupun di luar negeri. Pada tahun 1983 ia pernah menjadi Ketua Dewan Kesenian Jakarta. Pada tahun 1984 ia terpilih menjadi Ketua Umum PBNU. Dua tahun kemudian, yakni pada tahun 1986, ia dipercaya menjadi Ketua Festival Film Indonesia (FFI) dan anggota Dewan Pers Nasional. Pada Muktamar NU Ke-19 di Krapyak, Yogyakarta, ia kembali terpilih menjadi Ketua Umum PBNU untuk yang kedua kalinya. Kemudian pada Muktamar NU Ke-20 di Cipasung, Tasikmalaya pada tahun 1995, ia terpilih untuk yang ketiga kalinya sebagai Ketua Umum PBNU setelah mengalahkan Abu Hasan yang didukung oleh pemerintahan Soeharto. 
Gus Dur juga sering menjadi narasumber dalam seminar, baik di tingkat nasional maupun internasional. Sebagai tokoh LSM, ia sering tampil sebagai juru bicara LSM Indonesia di forum internasional semacam Acford di Bangkok. Ia juga pernah menghadiri komisi dialog dengan NOVIB tentang hak-hak asasi manusia. Sebagai pemikir nasional dan internasional, ia sering mendapat penghargaan bergengsi, seperti dinobatkan media massa sebagai “Tokoh 1999" newsmaker sehingga menjadi tokoh 1999. Dan, pada Maret 1999, ia diprediksikan sebagai kingmaker untuk Indonesia masa depan oleh sebuah majalah Singapura. Pada 13 Agustus 1993, Gus Dur bersama 4 warga Asia lainnya (Noburu Imamuru dari Jepang, Bano Coyaji dari India, Vo-Tong Xuan dari Vietnam, dan Brienvinido Lumberra dari Filipina) menerima hadiah Ramon Magsaysay di Manila, Filipina. Penghargaan itu diberikan berdasarkan keterlibatannya yang besar dalam upaya menumbuhkan toleransi agama di Indonesia. Pada 9 November 1994, Konferensi Sedunia Tentang Agama dan Kemanusian (World Conference on Relegion and Peace) yang bertempat di Rivadel Garda, Italia utara memutus-kan mengangkat Gus Dur sebagai salah satu presidennya. ${ }^{6}$

Rabu, 30 Desember 2009 Gus Dur wafat di Rumah Sakit Cipto Mangunkusomo Jakarta setelah dirawat beberapa hari karena sakit dan dimakam-kan di komplek Pesantren Tebuireng Jombang, Tawa Timur. Gus Dur wafat dalam usia 69 tahun, dengan meninggalkan satu orang istri, Sinta Nuriyah, dan 4 orang putri, Alissa Qotrunada Munawaroh (Lissa), Zanuba Arifah Khafsoh (Yenny), Anita Hayyatunnufus (Nita), dan Inayah Wulandari (Ina).

Kepulangan Gus Dur menyisakan duka yang mendalam bagi bangsa Indonesia, karena kehilangan tokoh agama, pejuang demokrasi, pemimpin politik, pembela kaum minoritas, pengusung hak asasi, pahlawan pluralisme, penganjur perdamaian, dan penentang kekerasan. Semua karyanya dijalaninya dengan sepenuh hati sebagai panggilan hidup, sekaligus sebagai perwujudan keyakinan dan nuraninya. Dalam memperjuangkan prinsip hidup, Gus Dur tidak pernah ragu-ragu, tegas, tanpa kehilangan rasa humor yang tertinggi. Ia dikenal sebagai sosok yang humoris

'Mujamil Qomar, NU 'Liberal', h. 167. 
dengan ucapanya yang sangat terkenal "gitu aja kok repot". Kini bangsa Indonesia kehilangan sosok pemersatu dan pembela kaum minoritas. Selamat jalan, Gus Dur, damai bersama-Nya, semoga anak bangsa mau belajar dengan ketokohanmu.

\section{B. Warisan Intelektual Gus Dur}

Gus Dur dikenal sebagai peneliti yang produktif sejak muda. Banyak karya tulisnya yang dihasilkan dalam bentuk makalah yang kemudian dikumpul-kan dan diedit ulang dan diterbitkan dalam bentuk buku yang banyak diterbitkan oleh LKiS Yogyakarta dan The Wahid Institute Jakarta. Di samping itu, ia juga menerjemahkan karya peneliti lain, memberikan pengantar pada buku-buku karya orang lain, dan membuat tulisan lepas yang tersebar di berbagai media massa, seperti surat kabar dan majalah, di antaranya Kompas, Media Indonesia, Prisma, Tempo, Ulumul Qur'an, majalah pesantren, dan lain-lain. Dalam bentuk buku, di antaranya:

1. Bunga Rampai Pesantren (1970). Buku ini merupakan pemaparan Gus Dur atas pemahaman fikih yang berkembang di pesantren dengan tantangan realitas kehidupan yang sedang berubah. Dalam buku ini tampaknya Gus Dur ingin menjelaskan kepada dunia luar tentang Islam di dunia pesantren dalam wacana Islam modern. Pada era tahun 1970-an, pesantren masih dianggap tertinggal jika dibanding dengan pendidikan di luar pesantren.

2. Muslim di Tengah Pergumulan (1981). Buku ini berupa bunga rampai kumpulan karangan, diterbitkan oleh Lembaga Pembangunan Nasional (Lepanas). Pada buku yang kedua ini, Gus Dur lebih menitikberatkan pada peran dan tanggung jawab Islam dalam kaitannya dengan isu-isu pembangun-an yang dihadapinya. Dalam buku ini Gus Dur ingin menceritakan bahwa peran agamawan sangat penting untuk ikut membangun masyarakat. Untuk itu, mereka harus memulai dari pemahaman yang benar akan keadaan masyarakat dan keadaan yang dialami oleh sebagian besar bangsa ini.

3. Kiai Nyentrik Membela Pemerintah (1997).

4. Tuban Tidak Perlu Dibela. Buku ini mengajak kepada para pembaca untuk memikirkan persoalan-persoalan kenegaraan, 
kebudayaan, dan keislaman. Terkait dengan agama, buku ini mempersoalkan fenomena agama dan kekerasan politik yang belakangan ini banyak terjadi. Agama dan kekerasan politik menjadi perhatian serius Gus Dur. Menurut Gus Dur, kekerasan politik merupakan akibat dari perilaku kaum fundamentalis agama yang berakar dari fanatisme sempit.

5. Cita dan Fakta, terjemahan dari buku Seyyed Hossein Nasr, yang diterbitkan oleh Lembaga Pembangunan Nasional.

6. Islamku, Islam Anda, Islam Kita: Agama Masyarakat Negara Demokrasi (2006), yang diterbitkan oleh The Wahid Institute. Buku ini berupa kumpulan esai-esai Gus Dur pascalengser dari Presiden, dan sebagian dari tulisan-tulisan yang sudah pernah diterbitkan oleh beberapa media massa seperti Kompas dan media lainnya.

7. Pengantar sejumlah buku, seperti Nabdlatul Ulama, Tradisional Islam, and Modernity in Indonesia yang diedit Greg Barton dan Greg Fealy; Kitab Kuning, Pesantren, dan Tarekat karya Martin van Bruinessen; "Hassan Hanafi dan Eksperimentasinya", dalam Islam Kiri, antara Modernisme dan Postmodernisme: Telaah Kritis atas Pemikiran Hassan Hanafi karya Kazuo Shimogaki; dan Nabdlatul Ulama dan Pancasila karya Einar M. Sitompul.

8. Tulisan-tulisan Gus Dur lainnya banyak tersebar di majalah dan surat kabar, seperti Aula, Prisma, Santri, Studi Islamika, dan Kompas. $^{7}$

\section{Latar Belakang Pemikiran Insiklusivisme Gus Dur}

Sebagaimana dijelaskan pada bab terdahulu, bahwa pemikiran dan perilaku manusia secara umum dipengaruhi oleh tiga faktor. Pertama, pandangan kultural. Cara pandang ini melihat bahwa cara berpikir seseorang biasanya dipengaruhi oleh sistem prakonsepsi yang tertanam sejak masih kecil akibat lingkungan sosialnya. Maksudnya, secara sosiologis, pemikiran seseorang tidak bisa dipisahkan dengan pengaruh lingkungan di mana seseorang itu hidup dan melakukan interaksi sehari-hari. Kedua, kedudukan sosial. Pandangan seseorang dipengaruhi oleh klasifikasi kelas sosial dan

7Mujamil Qomar, NU “Liberal”, h.167-168. 
posisi sosialnya. Ketiga, dipengaruhi oleh kecenderungan emosi personalnya. ${ }^{8}$

Dengan berpedoman pada pendapat di atas, bisa dipahami bahwa pemikiran-pemikiran yang berkembang di dunia pesantren, di mana Gus Dur lahir dan dibesarkan, lebih tepatnya lagi pemikiran-pemikiran Gus Dur tidak bisa lepas dari pemikiranpemikiran ayahnya, yakni K.H. Wahid Hasyim. Ingatan akan masa lalu Gus Dur tentang sosok sang ayah yang menjadi salah satu tokoh kemerdekaan RI, menjadi Menteri Negara pada Kabinet Pertama yang disusun Presiden Soekarno (September 1949) dan setelah penyerahan kedaulatan RI serta berdirinya RIS, dan dalam Kabinet Hatta tahun 1950, K.H. Wahid Hasyim diangkat menjadi Menteri Agama. Jabatan sebagai Menteri Agama disandangnya selama tiga kali kabinet, yakni Kabinet Hatta, Kabinet Natsir, dan Kabinet Sukirman. ${ }^{9}$ Karena ketokohannya itu, sang ayah memiliki banyak teman dan sahabat, baik dari kalangan Muslim, nasionalis, maupun non-Muslim. Rumah K.H. Wahid Hasyim yang terletak di Jl. Amir Hamzah, Jakarta Pusat, kini menjadi kantor The Wahid Institute, dahulu sering digunakan oleh ayah Gus Dur menerima tamu dari berbagai elemen masyarakat, untuk bersilaturahmi dan bertukar pikiran. Secara tidak langsung, Gus Dur yang waktu itu masih anak-anak ikut berinteraksi dan komunikasi dengan tamu atau teman-teman ayahnya. Peristiwa itu memberikan pemahaman bahwa ayahnya adalah seorang tokoh besar yang memiliki banyak kawan dan terbuka, bisa bergaul dengan banyak kalangan. Memori dan ingatan itu akan terus dibawa oleh Gus Dur sampai dewasa, yang menurut hemat penulis, banyak ikut mewarnai pemikiran Gus Dur di kemudian hari.

Menurut Shofiyullah, corak pemikiran K.H. Wahid Hasyim atau ayah Gus Dur adalah moderat, subtantif, dan inklusif (moderat dalam politik, subtantif dalam tujuan, dan inklusif dalam beragama). Corak pemikiran K.H. Wahid Hasyim seperti itu tampaknya banyak mengilhami pemikiran putra sulungnya, seperti kata pepatah, "Buah

8Shofiyullah, K.H. Wahid Hasyim: Sejarah Pemikiran dan Baktinya bagi Agama dan Bangsa (Jombang: Pondok Pesantren Tebuireng, 2011), h. 53.

I'Ibid., h. 55-56. 
kelapa jatuh tidak jauh dari batangnya." Artinya, pemikiran Gus Dur tidak jauh berbeda dengan pemikiran orang tuanya.

Namun, karena faktor pendidikan dan pengalaman waktu studi di Mesir, Bagdad, dan Eropa yang memberikan iklim lebih egaliter, demokratis, dan liberal, membuat Gus Dur melebihi pemikiran yang dimiliki sang ayah. Sebagian pengamat seperti Greg Barton dan Azyumardi Azra menyebut Gus Dur sebagai pemikir liberal jika dilihat dari perspektif tradisi pemikiran pesantren (ulama $\mathrm{NU}$ ), kitab-kitab standar yang dijadikan referensi ulama NU, Konferensi Besar Syuriah NU, Hasil Musyawarah Nasional Alim Ulama, ataupun hasil keputusan Muktamar NU.10 Banyak gagasan para cendekiawan NU seperti Gus Dur, Said Aqiel Siraj, dan Masdar Farid Mas'udi dikenal luas memiliki keberanian melontarkan pemikiran-pemikiran liberal (berlawanan dengan tradisi mereka), bukan saja oleh kalangan nahdliyin, tetapi juga menurut penilaian umat Islam keseluruhan di Indonesia. Namun, al-Zastrow, mantan ajudan Gus Dur, tidak setuju kalau dikatakan bahwa Gus Dur berpikir liberal. Menurutnya, Gus Dur itu tradisional, tetapi ia menghargai dan menerima pemikiranpemikiran progresif yang berkembang di kalangan cendekiawan dan anak-anak muda. Berpikir liberal itu kalau lepas dari budaya dan agama, sedangkan Gus Dur berpikirnya tidak pernah lepas dari konteks budaya dan agama secara umum. ${ }^{11}$ Pendapat yang hampir sama dikatakan oleh Ahmad Suaedy, Dewan Redaksi Jurnal Tashwirul Afkar dan Executive Director The Wahid Institute. Menurutnya, cara berpikir Gus Dur berusaha mengintegrasikan antara tradisionalisme pesantren yang penuh dengan nilai-nilai lokal dengan modernisme dari Barat yang maju dan progresif, sehingga menghasilkan gaya pemikiran yang kosmopolit. ${ }^{12}$ Yakni, maju, bermartabat, dan progresif, tetapi tetap tidak lepas dari nilai-nilai tradisional yang dianggap baik untuk dipertahankan, karena sesuai dengan semangat dan sifat masyarakat tradisional yang masih kental dengan tradisi yang dimiliki.

${ }^{10}$ Mujamil Qomar, NU 'Liberal', h. 21.

${ }^{11} \mathrm{Al}$-Zastrow, wawancara, 27 Mei 2013 di Bandar Lampung.

${ }^{12}$ Ahmad Suaedy, wawancara, 23 Februari 2013, di Gus Dur Corner Perpustakaan Universitas Indonesia Depok. 
Pemikiran progresif Gus Dur yang dianggap "liberal" dan progresif oleh sebagian kalangan nahdliyin (orang-orang yang mengkuti ajaran dan tradisi NU) dan masyarakat luar itu bisa dipahami, mengingat sebagian besar warga nahdliyin tinggal di desa-desa yang hidup di tengah budaya agraris yang berpikiran sederhana. Karena faktor inilah, menurut Mujamil Qomar, tidak memungkinkan Islam yang berkembang secara rasional dan modern. ${ }^{13}$

Sementara, Gus Dur sejak muda sudah senang membaca dan mempelajari teori-teori sosial, seperti Das Kapital karya Marx, What is to be Done karya Lenin, juga tulisan-tulisan filsuf Plato dan Aristoteles. Bahkan, ketika Gus Dur tinggal di Tegalrejo, Magelang di Pesantren K.H. Khudhori, Gus Dur banyak menghabiskan sebagian waktunya di luar kelas dengan membaca buku-buku Barat. Hal ini ditambah dengan kematangan ilmu-ilmu agama yang diperoleh dari nyantri di beberapa tempat, maka sangat rasional jika Gus Dur memiliki kelebihan keilmuan dibanding para kiai yang hanya belajar di pesantren. ${ }^{14}$ Maka, wajarlah kalau Gus Dur memiliki kemampuan keilmuan yang komprehensif, mendalam, dan cara pandang yang dianggap terlalu maju (liberal) dibanding para kiai sepuh yang cenderung konservatif karena perbedaan wacana atau referensi yang dimiliki. Apalagi masyarakat awam yang tingkat pengetahuannya terbatas, maka wajar jika sulit mengikuti pemikiran-pemikiran Gus Dur yang progresif itu.

Namun demikian, Gus Dur tetaplah sosok kiai NU yang tidak bisa lepas dari tradisi pesantren yang gemar ziarah kubur, membaca shalawat, membaca Barzanji, menghormati ulama, dan menjaga kelangsungan tradisi Islam ala Ahlussunnah wal Jamaah yang diikuti oleh mayoritas masyarakat NU dan masyarakat Indonesia. Apalagi Gus Dur adalah anak tertua K.H. Wahid Hasyim dan cucu K.H. Hasyim Asy'ari pendiri NU.

13 Baca Mujamil Qomar, NU 'Liberal”, h. 46-47.

${ }^{14}$ Greg Fealy menceritakan bahwa ia pernah mengunjungi Pondok Pesantren Denanyar pada awal 1990, dan kepadanya diperlihatkan dengan bangga oleh seorang warga yang memiliki lemari tua yang merupakan peninggalan Gus Dur yang penuh dengan buku-buku asing yang dibacanya ketika tinggal di pesantren ini selama 20 tahun. Baca Greg Barton, Biografi Gus Dur, h. 52. 
Dari uraian di atas, bisa dipahami bahwa corak pemikiran Gus Dur kosmopolit (mengintegrasikan modernisme dan tradisionalisme), inklusif (terbuka, menerima hal-hal baru yang dianggap lebih baik), progresif (maju, bahkan dalam hal-hal tertentu melewati batas-batas kebiasaan yang ada). Adapun inklusiv Gus Dur bisa dikatakan terkait dengan upaya menjaga dan melestarikan warisan budaya dan praktik pengamalan Islam ala Ahlussunnah wal Jamaah yang dilakukan oleh para ulama NU dan kiai pesantren, yang juga warisan dari ayah dan kakeknya. Dan, paham ini sudah menjadi bagian yang tidak terpisahkan dengan kehidupan masyarakat Islam Indonesia, terutama di Jawa yang tinggal di desadesa yang merupakan basis warga nahdliyin.

\section{Masyarakat Beragama yang Dicita-citakan Gus Dur}

Sebagai seorang pemimpin, cendekiawan Muslim, dan dai, Gus Dur pasti mempunyai impian-impian dan cita-cita yang ingin dicapai dalam perjuangan hidupnya, terlebih dalam kehidupan beragama di tanah air Indonesia ini. Sebab, tidak mungkin seorang Gus Dur berbuat tanpa dilandasi oleh tujuan yang ingin dicapai. Demikian halnya manusia pada umumnya yang wajar dan sehat, tidak mungkin melakukan suatu tindakan tanpa memiliki motif atau tujuan tertentu. Dengan adanya tujuan yang jelas, akan mempermudah dalam menyusun langkah-langkah yang harus dilakukan untuk mencapai tujuan tersebut.

Lalu apa sebenarnya yang menjadi cita-cita Gus Dur dalam hal kehidupan beragama? Sebagaimana ditulis oleh Djohan Effendi,

Gus Dur mendambakan kehidupan beragama yang ramah. Masing-masing umat beragama meyakini kebenaran agama yang mereka anut, sebab hanya dalam keyakinan yang tulus terletak makna keberagamaan yang hakiki, tetapi pada saat yang sama mereka juga seyogianya menghormati orang lain untuk meyakini kebenaran agama yang mereka anut dan melaksanakan secara bebas. ${ }^{15}$

${ }^{15}$ Djohan Effendi, "Kehidupan Umat Beragama dalam Cita-cita Gus Dur", dalam Irwan Suhanda (ed.), Gus Dur Santri Par Excellence: Teladan Sang Guru Bangsa (Jakarta: Kompas, 2010), h. 129.

456 Copyright @ 2016, KALAM, p-ISSN: 0853-9510, e-ISSN: 2540-7759 
Suasana saling menghormati itu juga tentu saja berlaku di antara pemeluk agama apapun. Sebab, dalam masing-masing umat satu agama juga terbuka perbedaan bahkan pertentangan keyakinan, tetapi mereka tidak perlu menjegal satu sama lain. Semuanya berhak hidup di bumi Tuhan yang satu.

Dengan kata lain, Gus Dur tampaknya ingin melihat bahwa dalam taman Indonesia, aneka macam bunga biarlah tumbuh secara wajar tanpa diganggu dan dihalang-halangi, apalagi dipaksa-paksa. Karena itu, semangat untuk main tunggal-tunggalan akan membunuh keragaman dan pasti akan membuat sejumlah pihak merasa diperlakukan tidak adil atau dirugikan. Sebab, biasanya yang menang adalah mereka yang kuat, kaya, dan bisa memperalat penguasa, tanpa malu-malu menggunakan cara-cara yang Machiavelis, tidak peduli halal atau haram, yang penting tujuan tercapai.

Hal semacam ini sangat ironis bila terjadi dalam kehidupan umat beragama. Gus Dur juga tidak ingin kehidupan beragama berhenti dalam suasana status quo, di mana lembaga-lembaga keagamaan tidak berfungsi sebagai pemberdayaan masyarakat, bahkan yang terjadi justru dijadikan alat untuk melakukan kooptasi atau paling tidak termanipulasi oleh kepentingan pribadi dan golongan.

Oleh karena itu, dalam pemikiran Gus Dur, Kementerian Agama atau Departemen Agama pada era pemerintahan Gus Dur, sebagai aparat negara adalah milik semua orang dan melayani semuanya. ${ }^{16}$ Oleh karena itu, Gus Dur meminta agar Departemen Agama bekerja secara adil dan bijaksana dengan memerhatikan semua elemen bangsa. Dalam pandangan Gus Dur, semua umat beragama mempunyai kebebasan untuk bereksistensi dan berekspresi sesuai dengan keyakinanya.

Apa yang dikatakan Gus Dur sebenarnya berangkat dari landasan normatif yang bersumber dari wahyu dan nash yang jelas, di mana dalam agama Islam, kemerdekaan beragama sangat dijamin. Bahkan, di antaranya hak untuk tidak beriman. Dijelaskan dalam al-Qur'an:

16Ibid., h. 128. 
Dan, jikalau Tubanmu menghendaki, tentulah beriman semua orang yang di muka bumi selurubnya. Maka, apakah kamu (bendak) memaksa manusia untuk beriman semuannya? (Q.S. Yunus [10]: 99)

Dalam ayat yang lain al-Qur'an juga menegaskan bahwa:

Bagimu agamamu dan bagiku agamaku. (Q.S. al-Kafirun [109]: 6)

Kalau al-Qur'an saja mengatakan seperti itu, mengapa kita justru yang memaksa agar orang lain mengikuti kita? Pertanyaannya, apakah kita lebih tahu dari al-Qur'an atau tepatnya apakah kita lebih mengerti dibanding Allah swt.? Jawabannya, tentu saja tidak. Sebab, sepandai apapun manusia, ilmunya terbatas dan tidak sanggup mengurai seluruh rahasia firman Allah swt.

Memang dalam perspektif dakwah kita boleh menawarkan jalan kebenaran, tetapi kita tidak boleh merasa paling benar. Agama boleh menawarkan keselamatan, tetapi jangan merasa paling selamat sendiri. Pendeknya, dalam melakukan ajakan kepada manusia untuk mengikuti perintah agama, kita dilarang untuk melakukan pemaksaan. Lihat firman Allah swt. dalam Al-Qur'an:

Kami lebih mengetabui tentang apa yang mereka katakan, dan kamu sekali-kali bukanlah seorang pemaksa terhadap mereka. Maka, berilab mereka peringatan dengan Al-Qur'an, orang-orang yang takut dengan ancaman-Ku.” (Q.S. Qaf [50]: 45)

Dari ayat-ayat di atas, jelaslah bahwa sikap memaksakan kehendak tidak diperkenankan dalam Islam. Sebab, sikap seperti itu hanya akan menjauhkan simpatik orang lain. Alangkah semangatnya Nabi Muhammad saw. dalam mengajak pamannya, Abu Thalib, yang sangat dicintai untuk masuk dalam risalah yang dibawanya. Nyatanya, keinginan tersebut tidak tercapai, sampai akhir hayatnya, Abu Thalib belum sempat menyatakan diri mengikuti ajakan Nabi Muhammad saw. Dengan demikian, nyatalah firman Allah swt.:

Sesunggubnya engkau tidak (mampu) memberikan bidayah kepada orang-orang yang kamu sukai, akan tetapi Allah (yang) memberikan bidayah kepada siapa yang dikehendaki, dan Dia lebih mengetabui orang-orang yang mendapat hidayah itu. (Q.S. al-Qashash [28]: 56) 
Dengan landasan normatif sebagaimana dijelaskan dalam Al-Qur'an itulah yang dijadikan pegangan Gus Dur dalam komitmennya membangun kebersamaan dalam kehidupan umat beragama, meskipun terkadang terlihat tidak konsisten dan zigzag. Kata Djohan Effendi, "Sebenarnya ia tetap setia pada komitmen dasarnya pada humanisme universal, tetapi juga terikat pada konteks ruang dan waktu, termasuk dalam hal cita-cita keberagamaan." ${ }^{17}$ Cita-cita dan komitmen kehidupan keagamaan yang diinginkan Gus Dur sesungguhnya tidak jauh berbeda dengan cita-cita pendahulunya, yakni ayahnya K.H. Wahid Hasyim dan kakeknya K.H. Hasyim Asy'ari.

Kalau ditarik benang merah antara cita-cita kehidupan beragama yang diimpikan Gus Dur dengan Qanun Asasi yang dibuat kakeknya, maka akan diperoleh kesamaan pandangan dan cita-cita antara keduannya, yakni penekanan pentingnya menciptakan kedamaian, persatuan, kesatuan, saling menghormati di antara anggota warga masyarakat tanpa membedakan suku, agama, asal usul keturunan, serta tolong-menolong demi terciptanya kebahagiaan bersama. Dan, itulah sesungguhnya spirit yang diajarkan oleh semua agama, termasuk agama Islam. Seperti namanya, Islam hadir di dunia sebagai pedoman manusia untuk.

\section{E. Insklusivitas Pemikiran Islam Gus Dur}

1. Pribumisasi Ajaran Islam

Diantara pemikiran inklusif Gus Dur yang menonjol adalah tentang pribumisasi ajaran Islam. Ide tentang perlunya pribumisasi ajaran Islam ini pernah memicu polemik di kalangan santri dan ilmuwan di Indonesia yang konon semakin melambungkan namanya di kalangan para cendekiawan di tanah air. Apa yang dimaksud dengan pribumisasi ajaran Islam? Pribumisasi ajaran Islam adalah pemahaman terhadap nash, baik yang bersumber dari Al-Qur'an maupun hadis, dikaitkan dengan masalah-masalah di negeri ini. ${ }^{18}$ Atau, dengan kata lain, pribumisasi Islam adalah

${ }^{17 D j o h a n ~ E f f e n d i, ~ " K e h i d u p a n ~ U m a t ~ B e r a g a m a ”, ~ h . ~} 130$.

18Abdurrahman Wahid, "Nahdlatul Ulama dan Khittah 1926", dalam M. Mansyur Amin dan Ismail S. Ahmad (ed.), Dialog Pemikiran Islam dan Realitas 
bagaimana memahami dan memaknai pesan-pesan Islam dalam konteks budaya di Nusantara. Meskipun Islam datang dari Jazirah Arab yang tentu saja tidak bisa dipisahkan dengan tradisinya, tetapi ketika sudah masuk ke Indonesia dan berdioalog dengan kebudayaan Nusantara, bagaimana Islam bisa diterima dan dilaksanakan dengan tidak mengubah kebudayaan yang sudah ada.

Menurut Gus Dur, kita perlu menghargai budaya melalui pribumisasi Islam. Intinya, bagaimana memasukkan sebanyak mungkin budaya lokal ke dalam Islam. ${ }^{19}$ Untuk melakukan gerakan pribumisasi Islam ini perlu keterlibatan semua elemen masyarakat dalam rangka mengukuhkan kembali akar budaya masyarakat.

Latar belakang pemikiran Gus Dur dengan melakukan pribumisasi Islam ini, menurut penulis, tidak lepas dari fenomena keagamaan yang berkembang di masyarakat Indonesia pada akhirakhir ini, di mana banyak masyarakat Muslim yang lebih suka menggunakan bahasa dan simbol-simbol Arab. Misalnya, penggunaan panggilan "abah" untuk mengganti kata "bapak", mengganti nama "mushalla" yang tadinya disebut "langgar", panggilan "ustaz" untuk memanggil "guru", dan sebagainya. Masjid yang beratap genteng, yang sarat dengan simbolisasi lokal, diganti dengan kubah. Budaya Walisongo yang serba Jawa, Seudati Aceh, dan Tabut Pariaman digeser dengan kasidah dan nasyid. Bahkan, ikat kepala lokal (udeng orang Jawa) harus mengalah dengan sorban model Yasser Arafat, dan seterusnya.

Di samping itu, ada upaya yang dilakukan oleh para ustaz atau dai yang belajar dari Arab untuk penyeragaman pandangan menyeluruh terhadap semua aspek kehidupan dari negara-negara Arab yang kaya ke daerah-daerah Muslim dengan tampilan formalisasi Islam. Hukum agama harus diseragamkan dan diformalkan. Harus ada sumber pengambilan formalnya, Al-Qur'an dan hadis, padahal dahulu cukup apa kata kiai. ${ }^{20}$ Para pengusung formalisasi Islam itu juga menekankan bahwa pandangan politik Islam yang benar hanyalah paham Sayyid Qutub, Abul A'la al-

Empirik (Yogyakarta: Lembaga Kajian dan Pengembangan Sumberdaya Manusia - LKPM NU, 1993), h. 152.

${ }^{19}$ Mujamil Qomar, NU “Liberal”, h. 174.

20Abdurrahman Wahid, "Salahkah Jika Dipribumisasikan?”, dalam Tuban Tidak Perlu Dibela (Yogyakarta: LKiS, 1999), h. 106. 
Maududi, atau Imam Khomaini. Pendapat lain yang sarat dengan pandangan lokal dinyatakan salah dan batil. Kalau sudah semacam ini, maka kehidupan kaum Muslimin akan tercerabut dari akar budaya lokalnya. Dengan demikian, maka Islam akan terlepas dari kerangka kesejarahan dari masing-masing tempat. Di Mesir, Suriah, dan Aljazair, Islam dibuat menentang nasionalisme Arab yang juga masing-masing berbeda-beda warna ideologinya.

Pertanyaan Gus Dur, anehkan jika ada keinginan sederhana, bagaimana untuk melestarikan akar-akar budaya lokal yang telah memiliki Islam di negeri ini? Mengapa orang-orang Islam mengganti atap masjid dengan kubah ala Timur Tengah atau India? Mengapa kaum Muslimin berkasidahan Arab melupakan "pujian" berbahasa lokal Jawa dan Sunda setiap akan melakukan sembahyang? Mengapa harus menggunakan kata "shalat", kalau kata "sembahyang" juga sama benarnya? Mengapa orang lebih sreg menggunakan kata "milad" untuk merayakan ulang tahun atau hari jadi?

Kesemuanya itu menunjukkan adanya tuntutan untuk membalik arus sejarah perjalanan Islam di negeri kita, dari formalisme berbentuk "Arabisasi total" menjadi kesadaran perlunya dipupuk kembali akar-akar budaya lokal dalam rangka kesejahteraan kita sendiri, dalam rangka mengembangkan kehidupan beragama Islam di negeri ini. Menurut Gus Dur, digunakannya istilah pribumisasi Islam, karena ia merasa kesulitan untuk mencari kata yang lain. Hal yang dipribumikan adalah manifestasi kehidupan Islam belaka, bukan yang menyangkut inti keimanan dan peribadatanya formalnya. Tidak diperlukan Al-Qur'an Batak dan hadis Jawa. Islam tetap Islam, di mana saja berada. Akan tetapi, tidak semua harus disamakan bentuk luarnya.

Penolakan Gus Dur terhadap "arabisasi budaya” lebih dikarenakan kecintaannya yang mendalam tentang Indonesia, yang menurutnya bangsa Indonesia telah memiliki budaya yang khas yang tidak kalah dibanding dengan budaya Arab dan lainnya. Lagi pula semua yang berasal dari Arab belum tentu cocok untuk dipakai di Indonesia yang multikultural.

Menurut Gus Dur, kalau kita menolak melakukan pribumisasi, kita lebih mundur dari prestasi para wali. Hal ini menyebabkan Islam tidak bisa melayani dunia di luar pesantren. 
Pemakaian kata "santri" dan "kiai" adalah hasil dari pribumisasi Islam. Jika kita hanya mau menggunakan kata "syekh" dan membuang kata "kiai", kita telah melakukan kemunduran. ${ }^{21}$ Mengapa kita mesti memakai sorban kalau ada kopiah yang lebih praktis, apa perlunya jubah kalau sarung masih ada. Secara substansi, memakai sorban dan jubah bukanlah suatu keharusan. Di sisi lain, pakaian tradisi yang memiliki fungsi yang sama seharusnya dilestarikan karena telah menjadi kebiasaan yang baik di masyarakat. Pakaian sarung dan kopiah tidak mengurangi sedikit pun makna pakaian dibanding dengan sorban dan jubah. Bahkan, masyarakat mengenal santri melalui pakaian sarung dan kopiah. Dua pakaian itu telah menjadi pakaian tradisi lokal sehingga penggunaannya telah mempribumi atau memasyarakat.

Sikap yang hanya mau menggunakan kata "syekh", sorban, dan jubah sebagai ilustrasi adalah fenomena formalisasi Islam dan Islamisasi perbuatan. Menurut Gus Dur, kecenderungan formalisasi ajaran Islam dalam kehidupan masyarakat dan Islamisasi perbuatan dalam bentuk manifestasi simbolik ini jelas tidak menguntungkan, karena hanya akan menimbulkan kekeringan substansi. ${ }^{22}$ Dengan munculnya para intelektual Islam yang serba mau memformalkan Islam, dikhawatirkan Islam akan kehilangan relevansi. Padahal, islamisasi yang ditawarkan itu baru sebatas pemakaian terminologi Arab yang berasal dari nash, atau arabisasi budaya. Padahal, arabisasi seperti itu akan membuat Islam semakin asing dan sulit melakukan adaptasi dengan lingkungan budaya setempat. Pada akhirnya, Islam akan kehilangan kesempatan yang baik untuk didakwahkan kepada masyarakat yang senantiasa melestarikan budayanya.

Sebaliknya, pribumisasi adalah sebuah kebutuhan, bukan untuk menghindari polarisasi antara agama dan budaya, sebab polarisasi memang susah dihindarkan. Seperti diakui Gus Dur, pribumisasi memang perlu, tetapi masih menghadapi batasanbatasan. Sebagai contoh, secara budaya, ucapan salam "assalamu 'alaikum" adalah sekadar ucapan baik-baik jika bertemu orang. Oleh

21"Dari Sekularisasi Cak Nur sampai Pribumisasi Cak Dur", dalam Majalah Aula, No. 6, Agustus 1987, h. 20.

22Mujamil Qomar, NU 'Liberal”, h. 175. 
karena itu, secara budaya bisa diganti dengan "selamat pagi", "punten", "kulo nuwun", dan lainnya. Akan tetapi, harus diingat bahwa di dalam salam itu ada dua norma. Pertama, memulai salam tidak wajib, tetapi menjawabnya adalah kewajiban, maka ketika menjawab, tidak bisa diganti dengan ucapan yang lain. Kedua, ucapan salam adalah bagian yang tidak bisa dipisahkan dengan shalat. Ketika ucapan Gus Dur ini dimuat oleh Majalah Amanah secara tidak lengkap, khususnya penjelasan dari sisi norma, maka terjadilah polemik di masyarakat, seakan Gus Dur mau menghapuskan ucapan salam yang merupakan identitas umat Islam. Padahal, yang dimaksudkan adalah bagaimana ucapan "assalamu 'alaikum" direlevansikan dengan kebutuhan kehidupan sehari-hari, bukan dipaksakan kepada semua orang. Jika lawan bicara belum terbiasa dengan ucapan "assalamu 'alaikum", gunakan saja ucapan salam yang lain yang sudah dikenal oleh masyarakat. Ini bukan berarti menghapuskan salam yang formal itu sendiri, tetapi memberikan kesempatan kepada orang lain untuk mengucapkan "salam lokal" bagi mereka yang masih kesulitan mengucapkan lafal "assalamu 'alaikum".

Meskipun sudah ada penjelasan yang terang dari Gus Dur tentang ucapan "assalamu 'alaikum", masih saja ada pihak lain yang memanfaatkan persoalan ini untuk berbagai kepentingan, termasuk kepentingan bisnis. Sebab, dengan mengangkat polemik soal ucapan salam yang dikemukakan Gus Dur, bisa meningkatkan oplah dan penjualan media tertentu. Maklum Gus Dur adalah tokoh yang dikenal dengan gagasan-gagasan yang cemerlang, bahkan kontroversial, ia berani menentang arus sehingga sering mengundang reaksi dari berbagai kalangan, tak terkecuali gagasan tentang mengganti ucapan salam dalam Islam dengan salam yang bersifat lokal. Kontan saja gagasan itu mendapat reaksi dari berbagai kalangan, dan Gus Dur pun “dipaksa” untuk melakukan klarifikasi ulang atas gagasanya tetang ucapan salam tersebut.

\section{Islam Sebagai Etika Sosial}

Ketidaksetujuan Gus Dur dengan formalisasi ajaran Islam dalam kehidupan berbangsa dan bernegara didasarkan pada keyakinannya bahwa bagi bangsa Indonesia yang majemuk, Islam tidak perlu dipaksakan menjadi undang-undang atau hukum negara, 
meskipun mayoritas masyarakat Indonesia beragama Islam. Sebaliknya Islam bisa dijadikan sebagai etika sosial (social ethics) dalam kehidupan berbangsa. Gus Dur dengan jelas menolak formalisasi Islam dalam politik nasional. Ia juga konsisten menjaga sikap politiknya, sebagaimana para pendahulunya di NU. Gus Dur menolak kehadiran negara Islam yang memang tidak diketemukan konsepnya. Ia berketetapan bahwa negara nasional atau negara bangsa (national state) yang berdasarkan Pancasila merupakan bentuk final dari Negara Kesatuan Republik Indonesia (NKRI).

Menurut Gus Dur, di dalam sebuah negara bangsa yang majemuk seperti Indonesia, Islam seharusnya diimplementasikan sebagai etika sosial, yang berarti Islam berfungsi sebagai komplementer dalam kehidupan negara. ${ }^{23}$ Menempatkan Islam sebagai etika sosial merupakan konstruksi yang seimbang (balance) antara keharusan mengambil nilai-nilai positif dari proses sekularisasi (bukan sekularisme) dan spiritualitas operatif sebagai manifestasi ketaatan terhadap ajaran agama.

Sebagai etika sosial, keislaman bisa termanifestasi dalam banyak wajah. Pertama, Islam akan menjadi agama yang terbuka, karena Islam sebagai etika. Islam terhindar dari kekakuan ajaran formalnya. Kedua, Islam akan menjadi sumber inspirasi bagi banyak orang, karena etika pada dasarnya bersifat universal. Ketiga, Islam akan menyatu sebagai bagian dari perubahan masyarakat secara keseluruhan.

Dalam pandangan Gus Dur, Islam tidak akan kehilangan kebesarannya dengan berfungsi sebagai etika masyarakat. Bahkan, kebesarannya akan meningkat, karena mampu mengembangkan diri tanpa dukungan masif dari institusi negara. Beragama Islam yang artinya tunduk dan patuh (taslim) sepenuhnya kepada Allah swt. adalah tujuan hidup yang luhur. Sebab, harus dihindarkan agar Islam tidak diletakkan di bawah kewenangan negara, melainkan menjadi kesadaran kuat dari warga masyarakat. Artinya, urusan agama adalah urusan sepenuhnya masyarakat, dan kehadiran negara hanya sebatas pada pengawas atau supervisi saja. Artinya, peran negara diperlukan jika terjadi persoalan yang tidak bisa diselesaikan

${ }^{23}$ Hanif Dhakiri, 41 Warisan Kebesaran, h. 102. 
oleh masyarakat itu sendiri. Memang hal ini tidak mudah untuk dilakukan, apalagi untuk masyarakat yang tingkat kedewasaan berpikirnya belum matang. Akan tetapi, masyarakat perlu diberi kepercayaan untuk menyelesaikan persoalannya sendiri tanpa intervensi negara, agar mereka menjadi mandiri dan dewasa. Bukankah lalu menjadi sangat mendalam makna hadis Nabi Muhammad saw. berikut ini.

Bahwasannya aku diutus untuk menyempurnakan kemuliaan akblak. (H.R. Ahmad) 24

Kemuliaan akhlak hanyalah terasa logis untuk disempurnakan, jika upaya itu diartikan sebagai pengembangan kesadaran mendalam akan etika sosial dari suatu masyarakat dan bangsa. ${ }^{25}$

Sebagaimana para dai pertama yang menyebarkan Islam di Nusantara yang dikenal dengan pendekatan sufistiknya, tampaknya Gus Dur lebih suka menempuh jalan sufi sebagaimana para Walisongo dalam memahami dan mendakwahkan agama. Yaitu, pemahaman yang lebih mengedepankan dimensi spiritual daripada demensi normatif, atau meminjam istilah Jalaluddin Rakhmat, "mendahulukan akhlak daripada fikih", Maksudnya, kalau mau mengukur kebaikan seseorang, lihat dari sisi hati dan kepribadiannya, bukan dari sisi penampilan fisiknya. Mengukur kesalehan seseorang jangan dari sisi sejauhmana ia telah melaksanakan perintah agama secara formal seperti shalat lima waktu, puasa Ramadan, dan pergi haji berapa kali, tetapi bagaimana sikap atau akhlak seseorang itu kepada orang lain; apakah ia memiliki kepedulian terhadap lingkungan sosial, apakah orangnya jujur, apakah ia santun, apakah ia tidak suka mengganggu tetangganya dengan lidah dan tangannya, dan lain-lain. Itulah yang dimaksud mengukur orang dari akhlaknya. Sebab, akhlak inilah yang menjadi missi utama diutusnya Nabi Muhammad saw. di muka bumi ini. Banyak hadis yang mengatakan bahwa ukuran keimanan seseorang tergantung dengan akhlak yang dimiliki.

${ }^{24}$ Ahmad ibn Hanbal, Musnad al-Imam Abmad ibn Hanbal (Beirut: Dar Ihya' at-Turas al-'Arabi, 1414 H/1993 M), jilid 2, h. 80, hadis no. 8.729.

${ }^{25}$ Abdurrahman Wahid, "Islam dan Masyarakat Bangsa”, dalam Majalah Pesantren, No. 3, Vol. VI, 1989, h. 9. 
Artinya, jika akhlak seseorang baik, maka baiklah iman seseorang. Sebaliknya, jika buruk akhlak seseorang, maka buruk pulalah iman seseorang.

Dengan begitu, Gus Dur bisa menghargai berbagai pemahaman, perilaku, bahkan perbedaan keyakinan di kalangan umat Islam sendiri ataupun di kalangan umat beragama lain. Gus Dur tidak pernah menyalahkan apalagi sampai menghakimi dan mencap sesat, bid'ah, dan kafir kepada mereka yang berbeda dengan pendapat yang umum. Sebab, Gus Dur memahami bahwa keyakinan harus dihargai dan dilindungi, sebagaimana tujuan diturunkannya syariat (maqasid asy-syari'ah), yakni menjaga dan melindungi keyakinan itu sendiri, apapun keyakinan yang dipilih manusia. Gus Dur mengajarkan kepada masyarakat Islam bahwa kemuliaan seorang Muslim bukan semata-mata terletak pada kesadarannya untuk memahami dan mengamalkan ajaran agamanya, tetapi juga pada kepedulian dan penghargaan kepada manusia lain dengan agama dan keyakinan yang dimilikinya. Menghargai orang lain adalah menghargai jiwa dan juga keyakinannya. Itulah penghargaan tertinggi dan penghargaan sejati. Jadi, menghargai manusia bukan karena pertimbangan agama tertentu yang seiman dan seagama, tetapi lebih dari itu, yakni karena kemanusiaannya.

\section{F. Kesimpulan.}

Dari uraian di atas bisa disimpulkan bahwa: pertama, sebagai cendikiawan yang lahir dan besar dari kalangan Nahdlyyin dan besar di Indonesia Gus Dur memiliki corak pemikiran inklusiv, terbuka menerima pemikiran dari Barat dan Islam, bahkan karena pengaruh pendidikan, dan kegemarannya dalam mengkaji pemikiran modern ia terkadang terkesan liberar.

Kedua, diantara inkusivitas pemikirannya, Gus Dur memandang perlu untuk dilakukan pribumisasi ajaran Islam dengan cara memahami Islam dalam kontek budaya Indonesia. Dengan cara memasukkan unsur budaya lokal (local wisdom) dalam memahami nas dan hadis sebagai sumber ajaran Islam. Dalam kehidupan beragama ia mendambakan kehidupan beragama yang damai, saling menghormati. Dimana setiap umat meyakini 
agamanya dengan ketulusan hati. Sebab hanya dengan keberagamaan yang tulus terletak makna keberagamaan yang hakiki. Gus Dur menolak keinginan dari sebagian muslim Indonesia yang menghendaki Islam menjadi undang-undang atau hukum Negara. Meskipun sebagian besar penduduk Indonesia beragama islam. Menurutnya, Islam cukup menjadi etika dalam bernegara. []

\section{DAFTAR PUSTAKA}

Ahmad ibn Hanbal, Musnad al-Imām Ahmad ibn Hanbal, Beirūt: Dār Ihyā' al-Turāì al-'Arabīy, 1414 H/1993 M.

Abdurrahman Wahid, "Salahkah Jika Dipribumisasikan?”, dalam Tuban Tidak Perlu Dibela, Yogyakarta: LKiS, 1999.

"Nahdlatul Ulama dan Khittah 1926", dalam M. Mansyur Amin dan Ismail S. Ahmad (ed.), Dialog Pemikiran Islam dan Realitas Empirik (Yogyakarta: Lembaga Kajian dan Pengembangan Sumberdaya Manusia - LKPM NU, 1993 , Islamku Islam Anda Islam Kita Agama masyarakat Negara

Demokrasi, Jakarta: The Wahid Institute, 2006.

, Islam Kosmopolitan Nilai-Nilai Indonesia Tranformasi dan Kebudayaan, The Wahid Institute, 2007.

Djohan Effendi, "Kehidupan Umat Beragama dalam Cita-cita Gus Dur", dalam Irwan Greg Barton, Biografi Gus Dur, Yogyakarta: LKiS, 2010.

M. Hanif Dhakiri, 41 Warisan Kebesaran Gus Dur, Yogyakarta: LKiS, 2010.

Mujamil Qomar, NU 'Liberal': dari Tradisionalisme Ablussunab ke Universalisme Islam, Bandung: Mizan, 2002.

Rosidi, Pemikiran Dan Gerakan dakwah Multikultural K.H. Abdurrahman Wabid Di Indonesia, Yogyakarta, UIN Sunan Kalijaga, 2015.

Suhanda (ed.), Gus Dur Santri Par Excellence: Teladan Sang Guru Bangsa ,Jakarta: Kompas, 2010.

Shofiyullah, K.H. Wabid Hasyim: Sejarah Pemikiran dan Baktinya bagi Agama dan Bangsa (Jombang: Pondok Pesantren Tebuireng, 2011), 


\section{Jurnal:}

Abdurrahman Wahid, "Islam dan Masyarakat Bangsa", dalam Majalah Pesantren, No. 3, Vol. VI.

\section{Hasil Wawancara :}

Al-Zastrow, wawancara, 27 Mei 2013 di Bandar Lampung.

Ahmad Suaedy, wawancara, 23 Februari 2013, di Gus Dur Corner Perpustakaan Universitas Indonesia Depok. 